\title{
Identification of Bacteria on Cockroach Feet (Periplaneta americana) in Resident Area of Teluk Palu Permai and Sensitivity Test Against Antibiotics
}

\author{
I Nengah Kundera ${ }^{1}$, Evasari Herman Sapu ${ }^{2}$, Mursito Bialangi ${ }^{3}$ \\ 1,2,3 Department of Biology Education, Faculty of Teachers Training and Education \\ Tadulako University Palu - Central Sulawesi, Indonesia \\ Email: ${ }^{1}$ nengahkundera@gmail.com; 2 evasarihsapu@gmail.com; ${ }^{3 m u r s i t o b i o l o g i @ y a h o o . c o . i d ~}$
}

$\begin{array}{ll}\text { Received } & : 18-04-2020 \\ \text { Accepted } & : 05-05-2020 \\ \text { Available online } & : 31-05-2020\end{array}$

Cockroaches (Periplaneta americana) a group of Arthropoda is living inside and outside the home because these animals can cause various diseases and act as vectors as well as hospes. Cockroaches and other animals that act as vectors are strongly associated with the presence of microorganism pathogen carried on their feet. This study aims to identify the bacteria in Cockroach feet at Teluk Palu Permai residential neighborhood and the sensitivity test against antibiotics. This research is an exploratory laboratory, using a standard of bacteria isolation, Gram staining, Microbact system, and antibiotic sensitivity test. The results of the research were successful in identifying bacteria from Cockroaches, obtained from residential environments bacteria thas is Escherichia coli, Klebsiella pneumoniae, Proteus vulgaris, Salmonella arizonae, and Proteus mirabilis. The discovery of this bacteria is initial research that is useful for the development of handling infectious diseases transmitted by Cockroach vectors. This study has also found that bacteria experience resistance to the antibiotics Vancomycin, Chloramphenicol and Amoxycillin. While Ciprofloxacin and Ofloxacin antibiotics are still sensitive to Escherichia coli bacteria, Klebsiella pneumoniae, Proteus vulgaris, Salmonella arizonae, and Proteus mirabilis. This research is expected to provide preliminary data on the role of Cockroach as a vector of infectious diseases for humans caused by pathogenic bacteria and prevention efforts in the future.

Keywords: Antibiotics, isolation, Periplaneta americana, sensitivity

\section{ABSTRAK}

Kecoa (Periplaneta americana) merupakan kelompok Artropoda yang hidup di dalam dan di luar rumah, karena hewan ini dapat menularkan berbagai penyakit dan bertindak sebagai vektor maupun sebagai hospes. Kecoa dan hewan lain yang bertindak sebagai vektor, sangat terkait dengan kehadiran mikroorganisme patogen yang terbawa pada kakinya. Penelitian ini bertujuan untuk mengidentifikasi bakteri pada kaki Kecoa (Periplaneta americana) di lingkungan Perumahan Teluk Palu Permai dan uji sensitivitas terhadap antibiotik. Penelitian ini bersifat eksploratif laboratorium, dengan menggunakan standar isolasi bakteri, pewarnaan Gram, Microbact system dan uji sensitivitas antibiotik. Hasil penelitian berhasil mengidentifikasi bakteri dari kaki Kecoa (Periplaneta americana), yang diperoleh dari lingkungan Perumahan Teluk Palu Permai yaitu bakteri Escherichia coli, Klebsiella pneumoniae, Proteus vulgaris, Salmonella arizonae, dan Proteus mirabilis. Kelima jenis bakteri ini telah mengalami resistensi terhadap antibiotik Vancomycin, Chloramphenicol dan Amoxycillin. Sedangkan antibiotik Ciprofloxacin dan Ofloxacin masih sensitif terhadap bakteri Escherichia coli, Klebsiella pneumoniae, Proteus vulgaris, Salmonella arizonae, dan Proteus mirabilis. Penelitian ini diharapkan dapat memberikan data awal peran Kecoa 


\section{TECHNO: Vol. 09 (01) Mei 2020}

sebagai salah satu vektor penyakit infeksi bagi manusia yang disebabkan oleh bakteri patogen dan usaha pencegahan di masa mendatang.

Kata kunci: Antibiotik, isolasi, Periplaneta americana, sensivitas

\section{INTRODUCTION}

Cockroach (Periplaneta americana) is often found to associate very closely with humans and present in large numbers in and around homes or hospitals, garbage dumps, in urban areas, in villages with poor sanitation (Bouamama et al., 2010). Unclean environmental conditions can be an excellent place for the proliferation of disease vectors. Vectors are invertebrate animals that act as infectious disease-causing agents from sick hosts to other vulnerable hosts (Nurcahyo et.al., 2012).

The cockroach is one of the insects that can transmit the disease because of the habitat Cockroaches like places that are moist, warm, dark and dirty. These places can be gaps around dumps in the kitchen, garbage dumps, warehouses, food cabinets, toilets and septic tanks. Cockroaches have an important role in disease transmission. This role is called a mechanical vector for pathogenic microorganisms. Cockroaches can move some microorganisms, especially bacteria either pathogenic or nonpathogenic bacteria (Nedelchev et al., 2013; Syed et al., 2014; Moges et al., 2016).

Pathogenic bacteria can cause diseases such as diarrhea, dysentery, cholera, and polio. Transmission of the disease can occur through pathogenic microbes contained in garbage or food scraps attached and carried by the feet or other body parts of Cockroaches, which had settled or paved in the place, then through the body organ, the microbe cockroach contaminated the food (Hammad \& Mahdy, 2012; Moges et al., 2016; Zacharia V.M., et al., 2013; Afe, 2015; Tatang et al., 2017). A home environment is a place for people to do all activities such as eating, drinking, and resting. Unhealthy lifestyles such as littering and poorly maintained home environments can become a breeding ground for disease-causing bacteria. Cockroaches are known to have been found and have distribution around the world. These domestic pests affect human health in several ways, as well as the habit of living Cockroaches make it an ideal mechanical vector of pathogenic microorganisms (Bouamama et al., 2010).

According to Lai, (2017); Kundera \& Bialangi, (2018); Astiti et al., (2018) states that Cockroaches and flies found in his research carried several species of bacteria on their external surfaces. Bacteria that have been isolated from insects Cockroaches are Gram-positive bacteria especially Staphylococcus and Streptococcus. While Gram-negative bacteria, especially group Enterobacteriaceae. Most of these bacteria are pathogenic such as Staphylococcus aureus, Staphylococcus epidermidis, Streptococcus sp, Escherichia coli, Enterobacter sp., Klebsiella sp., Serratia sp., Proteus vulgaris, Proteus sp., Shigella sp., and Salmonella sp. Some researchers have reported that bacteria isolated from hospital environments have experienced Multi-Drug Resistant (MDR) for example there are bacteria that are resistant to Ampicillin, Chloramphenicol, Tetracycline, and others (Moges et al., 2016). Therefore, in this study also has been tested the sensitivity of some antibiotics to the isolated bacteria from Cockroach feet.

Based on the potential of Cockroach as a vector spreader of various diseases that have not been studied in Central Sulawesi, it has been done isolation and identification of bacteria that can be found in Cockroach feet in a residential area and the sensitivity to antibiotics. This is 
important because increasing microbial resistance becomes a serious problem and takes a long time to find the right solution (Hasanah et al., 2017).

\section{MATERIALS AND METHOD}

This research is an explorative laboratory research with qualitative and quantitative analysis. The tools used in this research are photomicroscope, autoclave, incubator, camera Cannon, Laminar Air Flow and digital colony counter. While the materials used are bacteria from Cockroaches, NA medium, TSIA, EMB-Agar, MS-Agar, SS-Agar (OXOID), 96\% alcohol, 0.8\% $\mathrm{NaCl}$ solution, Microbact system Kit and soft ware to identify bacteria.

\section{Preparing Bacteria Growing Medium}

Preparing the medium used to grow bacteria for the isolation process. The medium is sterilized in an autoclave at a temperature of $121^{\circ} \mathrm{C}$ for 20 minutes. Bacteria that have been grown in the NA medium to take as much as 1 ose, inoculated aseptically on the surface of EMB-Agar medium and incubated for 24 hours at $35^{\circ} \mathrm{C}$. When bacteria colonies are metallic blue means positive growth of bacteria E. coli, and Gram staining was done. Perform the same procedure on different bacteria and media (Cappuccino, J.G. \& Sherman N., 2014).

\section{Isolation and Identification of Bacteria}

Five test tubes filled with cockroach foot fluid, after being diluted were inoculated in the NA medium. Bacteria that have been grown in NA medium to take as much as 1 ose, inoculated aseptically on the surface of Eosin Methylene Blue Agar medium and incubated for 24 hours at $35^{\circ} \mathrm{C}$. When bacteria colonies are metallic blue means positive growth of bacteria Escherichia coli, and Gram staining was done. Perform the same procedure on different bacteria and media. Biochemical tests were then performed using the Microbact KIT system and software to identify the bacteria that were isolated.

\section{Test the Sensitivity to Some Antibiotics}

To prove the nature of bacteria sensitivity to antibiotics, in this study standard procedures were used which were used by Bauer-Kirby manual in 1966 (Kirby et al., 1966; Islam et al., 2016; Tatang et al., 2017). In this study, using five types of antibiotic paper disks, according to NCCLS standards, namely: Chloramphenicol $(30 \mu \mathrm{g})$, Amoxicillin $(20 \mu \mathrm{g})$, Vancomycin $(30 \mu \mathrm{g})$, Ciprofloxacin $(5 \mu \mathrm{g})$, and Ofloxacin $(5 \mu \mathrm{g})$. This method is a well-established procedure for which there are accepted standards including those endorsed by the National Committee for Clinical Laboratory Standards (NCCLS) (Cockerill et al., 2007).

\section{RESULTS AND DISCUSSION}

\section{Characteristics of Bacteria Colonies}

To facilitate the identification of bacteria, bacteria were the culture on the Nutrien Agar medium has been obtained, so that the colonies are obtained and each colony is selected to be grown on a specific medium. After bacteria grow in NA media, bacteria colonies are transferred to specific media, to ensure that bacteria grow according to the specifications of the medium used, so they can show typical colonies. The results of this study found five characteristics of different bacteria colonies. Then each colony is matched with the standard characteristics of the colony for identification.

Based on the characteristics of colonies obtained on EMB-Agar medium with round characteristic, metallic green color with the irregular colonic surface, it is believed that the 


\section{TECHNO: Vol. 09 (01) Mei 2020}

bacteria is Escherichia coli bacteria (Figure 1 and Figure 2 at supplementary part), this is in accordance with the opinion of (Khakim \& Rini, 2018).

The bacteria are then characterized by a rounded, slightly turbid colony, with a flat colony surface suitable for the Klebsiella bacteria. It should be pointed out that Klebsiella spp., Is easy to grow in general media that is commonly used to isolate Enterobacteriaceae, for example, NA, Tryptic Casein Soybean Agar, Bromocresol Agar Purple Lactose, Blood agar, and special differential media for Enterobacteriaceae, such as Drigalski Agar, Mac Conkey-Agar, EMBAgar, and Bromo-Timol Agar Blue (BTBA). Klebsiella strains grow as yellow slimy colonies, while other members of Enterobacteriaceae do not grow well or produce small colonies that are pink, red or orange.

The next bacteria has the characteristics of a rounded colony, the color is turbid with a black center, with a rather flat surface of the colony, this belongs to the class of Proteus bacteria. Other bacteria colonies have around, white-gray color, with a flat colony surface, this matches the characteristics of the Proteus bacteria colony as well. The last bacteria has a rounded, opaque white color with a flat colony surface that grows on SSA media, this is some as to the characteristics of Salmonella bacteria (Gomes et al., 2016).

\section{Gram Stain Results of Bacteria Cells}

Observation of bacteria cell morphology is done through Gram staining. Gram bacteria staining is intended to classify bacteria into Gram-negative. These staining results prove that bacteria are classified as Gram-negative or Gram-positive bacteria. This greatly allows the bacteria carried by the Cockroach on its feet from a spot polluted by bacteria from animal or human waste. By the characteristic of Gram staining results that the bacteria group stained with Gram dye when producing a red color then the bacteria belong to Gram-negative group of bacteria, vice versa when blue then grouped into Gram-positive bacteria.

This is in line with the opinion of that Gram staining is a differential staining to distinguish bacteria species into two major groups (Gram-positive and Gram-negative), primarily based on the chemical and physical properties of their cell walls. Gram staining is not used to classify Archaea because microorganisms provide very varied responses. The morphology of the bacteria cell results of Gram staining found in Cockroach legs in the area of the house is as follows seen in Figure 3 to 4 (at supplementary part). According to the results of Pechal et al., (2013); Syed et al., 2014), several bacteria isolated from the collected sample showed a high prevalence $(92.3 \%)$ of microbes in the P. americana exoskeleton. The acquisition of Gramnegative bacteria and the spread of organisms such as $E$. coli is prevalent throughout the premises including the campus environment. The data from this study also reinforces the potential ability of Cockroaches to send pathogens mechanically.

Mass Cockroach Migration has been reported for several species because the population is large. The cockroach migration process to a new area usually by crawling or flying. Longdistance transport from these pests can occur on aircraft, ships or other vehicles. In certain circumstances Cockroaches release the secretions of nausea from the mouth and from the glands that open on the body that gives the smell durable, the smell of cockroaches spread the area or food visited. Identifying the Cockroach population aims to understand the ability of replacement species, which indirectly transfer disease-causing organisms including bacteria.

There are several pathogens associated with Cockroaches that are neglected during a sudden disease diagnosis with symptoms similar to food illness, including abdominal cramps, diarrhea, nausea, and fever. Analyzing the spatial distribution of E. coli and Campylobacter 
spp., from collected cockroaches is a prevalence of species of bacteria identified between populations (Hammad \& Mahdy, 2012), also reported that some bacteria isolated from several samples in the home environment showed a high prevalence $(92.3 \%)$ of the microbes found in the exoskeleton of $P$. americana.

According to Syed et al., (2014); Pechal et al., (2013); Tatang et al., (2017) some of these pathogens can lead to gastroenteritis along with other internal and external infections throughout the body, especially in areas with open wounds or other environments favorable to bacteria growth. The presence of the Coliform bacteria is a stable and significant part of the total coliform found at the household site. This is an indication that Cockroaches come in contact with soil bacteria such as Klebsiella, Enterobacter and Citrobacter species. This is an indication that Cockroaches come in contact with soil bacteria such as Klebsiella, Enterobacter and Citrobacter species. Some bacteria isolates are known for pathogens such as Salmonella, Shigella, B. cereus, while others as opportunistic pathogens are Pseudomonas, Klebsiella, and Vibrio, while those responsible for food decay are Pseudomonas, Enterobacter, Escherichia, and Erwinia. All of these bacteria species including bacteria groups have also been confirmed previously associated with Cockroaches.

According to Tatang et al., (2017); Ejimadu et al., (2015), reported that a total of 73 cockroaches were captured at night and identified as $P$. americana and have studied their microbial flora. The result is medically that important microorganisms have been isolated from the external surface of the examined Cockroach. Examination through external body washes of cockroaches reveals that Cockroaches are carriers of Klebsiella, Pseudomonas, E. coli, Staphylococcus, Serratia, Enterobacter, Streptococcus, Bacillus, and Proteus. Klebsiella spp. (47.9\%), Pseudomonas spp. (37\%), and E. coli $(30.1 \%)$ were the most frequently identified organisms. Furthermore, to observe the level of bacteria density in Cockroach feet then taken one of the samples to represent a dilution range of 10-5 s.d 10-7. Based on the calculation of bacteria colonies on the Nutrient Agar medium, we get the amount of Standard Plate Count (SPC) bacteria of $2.7 \times 106$ cells $/ \mathrm{mL}$. This shows how dense the bacteria content of Cockroach feet is so potential to carry microbial pathogens to humans.

\section{Biochemical Test Results and Microbact System}

To confirm the results of further biochemical tests conducted with Microbact system testing. The results of the validity level analysis of biochemical test on each type of bacteria can be seen in the following Table 1 (at supplementary part).

Based on the morphological characteristics of the colony than to strengthen the results of this identification followed by the biochemical test by growing bacteria on TSIA media. In this medium, each bacteria exhibits its ability to ferment sugars contained by the TSIA medium, so that the fermentation results can be seen as part of the bacteria metabolism process. The results of the test through on this medium in the first sample suspected $E$. coli bacteria due to changes in medium to yellow color means formed acid, and formed the gas. In the second sample was suspected to contain Klebsiella bacteria, there was a change of medium to acid and partly alkaline (red in color), meaning that the bacteria could only ferment glucose, similarly in the third sample. In the fourth sample, the opposite is true that bacteria can not ferment sugars, lactose, and sucrose or both because the slant and butt part of the media is red (alkaline), as well as in the fifth sample not fermenting the sugars then the slant and butt portions do not change color. However, in this test found the presence of gas, but not $\mathrm{H}_{2} \mathrm{~S}$, due to media motility. 


\section{TECHNO: Vol. 09 (01) Mei 2020}

Tests on the TSIA medium are used to determine whether Gram-negative bacteria ferment glucose, lactose or sucrose and form hydrogen sulfide $\left(\mathrm{H}_{2} \mathrm{~S}\right)$. TSIA contains 10 parts of lactose, 10 parts of sucrose, 1 part glucose and peptone. The red and iron sulfate phenol serves as an indicator of the acidification and formation of $\mathrm{H}_{2} \mathrm{~S}$, respectively. The formation of $\mathrm{CO}_{2}$ and gas is indicated by the presence of bubbles or cracks in the agar medium from the sides or bottom of the tube. While the production of $\mathrm{H}_{2} \mathrm{~S}$ is characterized by the black color of the bottom of the medium in the tube.

\section{The result of bacteria sensitivity test with Antibiotics}

Eight types of bacteria have been identified, but there are similarities in the types of bacteria found in the same area, so we used 5 samples of bacteria tested with antibiotics. The results of the sensitivity test to five bacteria namely, Escherichia coli, Klebsiella pneumoniae, Proteus vulgaris, Salmonella arizonae, Proteus mirabilis, can be seen the diameter of the inhibition zone in the following Figure 5 to 6 (at supplementary part). Based on the isolation result of all bacteria isolated from Cock's legs, five types of bacteria belonging to Gram-negative bacteria are $E$. coli, S. arizonae, P. vulgaris, K. pneunomiae, and Proteus mirabilis. All the bacteria that had been isolated were tested for sensitivity to some antibiotics. The five bacteria found to be resistant to Vancomycin antibiotics are E. coli, S. arizonae, P. vulgaris, K. pneunomiae and P. mirabilis. While antibiotics that still have good sensitivity to test bacteria are Ciprofloxacin antibiotics.

Therefore it is necessary to recommend the use of the five bacteria because it has good sensitivity to Proteus vulgaris and Klebsiella pneunomiae bacteria, but Escherichia coli, Salmonella arizonae, and Proteus mirabilis are resistant to this antibiotic. The results of the studies (Leshan Wannigama et al., 2013; Akter et al., 2018) suggest that even distribution of cockroaches in household environments could be a vector for the spread of drug-resistant and diseaseresistant bacteria.

Some researchers report multi-resistant bacteria against antibiotics that are isolated from Cockroaches especially isolates from hospitals (Kassiri et al., 2014) found that two Grampositive bacteria and five Gram-negative bacteria were resistant to Ampicillin (13.7\% to 100\%), Chloramphenicol $(14.3 \%$ to $71.4 \%)$, Tetracycline $(14.3 \%$ to $73.3 \%)$, and Sulfamethoxazole trimethoprim (14.3\% to 57.1\%). Similarly, (Leão-vasconcelos et al., 2015; Akter et al., 2018; Moges et al., 2016; Abdolmaleki et al., 2019), found that among the 96\% Enterobacteria resistant with Gentamicin, 84\% against Ampicillin, 75.3\% for Cephalothin, 66.7\% with Ampicillinsulbactam, $50 \%$ for aztreonam, 30\% against Chloramphenicol. This proves that cockroaches living in the home area carry resistant bacteria from their environment. But in this study, the number of bacteria that are more resistant to antibiotics are tested, compared to bacteria that are still sensitive to antibiotics although isolated in the home environment. Therefore it should be cautioned that the role of Cockroach as a vector of disease for humans good for groups of Gram-positive bacteria, Gram-negative, protozoa, and other parasites. Some researchers such as (Nedelchev et al., 2013; Al-fattly \& Al-aridhi, 2014), confirmed that pathogenic bacteria isolated from Periplaneta americana is one of the most important medically important pests found in human and hospital homes that cause serious health problems because it must be fought.

\section{CONCLUSION}

Based on the results of research and theoretical studies can be summarized as follows: Identified bacteria from Cockroach feet from the residential neighborhood of Escherichia coli 
bacteria, Klebsiella pneumoniae, Proteus vulgaris, Salmonella arizonae, and Proteus mirabilis. Bacteria isolated from Cockroach feet in the home environment have been resistant to antibiotics Vancomycin, Chloramphenicol, and Amoxycillin. While Antibiotics Ciprofloxacin and Ofloxacin still sensitive to the five bacteria $E$. coli, $K$. pneumoniae, P. vulgaris, $S$. arizonae, and Proteus mirabilis. This research is expected to provide preliminary data on the role of Cockroach as a vector of infectious diseases for humans caused by pathogenic bacteria and prevention efforts in the future.

\section{REFERENCES}

Abdolmaleki, Z., Mashak, Z., \& Safarpoor Dehkordi, F. (2019). Phenotypic and genotypic characterization of antibiotic resistance in the methicillin-resistant Staphylococcus aureus strains isolated from hospital cockroaches. Antimicrobial Resistance and Infection Control, 8(1), 1-14. https://doi.org/10.1186/s13756-019-0505-7

Afe, O. T. I. (2015). Microbiology of Cockroaches - A Public Health Concern. International Journal of Scientific Research, 4(4).

Akter, T., Ahmed, S., \& Biswas, R. (2018). Isolation and identification of some gram-negative bacteria from cockroaches collected from hospital, restaurant and slum areas of Dhaka City, Bangladesh. Journal of Biodiversity Conservation and Bioresource Management, 3(2),63-68. https://doi.org/10.3329/jbcbm.v3i2.36029

Al-fattly, H. H. H. H., \& Al-aridhi, H. S. (2014). Antibiotic resistant bacteria associated with the cockroach Periplaneta americana in Al-Diwaniya city / Iraq. 2(12), 709-714.

Astiti, P. M. A., Bialangi, M., \& Kundera, I. N. (2018). Identification of bacteria on Cockroach feet from Hospital area in Palu city and test of sensitivity to antibiotic. IOP Conference Series: Materials Science and Engineering, 434(1). https://doi.org/10.1088/1757-899X/434/1/012123.

Bouamama, L., Sorlozano, A., Laglaoui, A., Lebbadi, M., \& Aarab, A. (2010). Antibiotic resistance patterns of bacterial strains isolated from Periplaneta americana and Musca domestica in Tangier, Morocco Original Article Antibiotic resistance patterns of bacterial strains isolated from Periplaneta americana and Musca domestica. May. https://doi.org/10.3855/jidc.336

Cappuccino, J.G. \& Sherman N., (2014). New Features Make the Micro Lab More Clinical Application Gram Staining: The First.

Cockerill, F., Wikler, M., Bush, K., Craig, W., Dudley, M., Eliopoulos, G., \& Hecht, D. (2007). Performance Standards for Antimicrobial Susceptibility Testing; Seventeenth Informational Supplement. In Clinical and Laboratory Standars Institute - NCCLS (Vol. 27, Issue 1). https://doi.org/1-56238-525-5.

Ejimadu, L.C., Goselle, O.N., Ahmadu, YEntomology, A., \& Unit, P. (2015). Specialization of Periplaneta americana (American Cockroach) and Blattella germanica (German cockroach) Towards Intestinal Parasites. A Public Health Concern. 10(6), 23-32. https:// doi.org/10.9790/3008-10642332.

Gomes, T. A. T., Elias, W. P., Scaletsky, I. C. A., Guth, B. E. C., Rodrigues, J. F., Piazza, R. M. F., Ferreira, L. C. S., \& Martinez, M. B. (2016). Diarrheagenic Escherichia coli. Brazilian Journal of Microbiology, 47, 3-30. https://doi.org/10.1016/j.bjm.2016.10.015.

Hammad, K. M., \& Mahdy, H. M. (2012). Antibiotic resistant-bacteria associated with the cockroach, Periplaneta americana collected from different habitat in Egypt. New York Science Journal N Y Sci J, 55(1212),198-206.

http://www.sciencepub.net/newyork\%0Ahttp://www.sciencepub.net/newyork.

Hasanah, U., Riwayati, R., Idramsa, I., \& Prasetya, E. (2017). Molecular Identification of Endophytic Fungi from Bark of Raru (Cotylelobium melanoxylon) that Produce the Antibacterial Compounds. 


\section{TECHNO: Vol. 09 (01) Mei 2020}

Biosaintifika: Journal of Biology $\mathcal{E}$ Biology Education, $9(3), \quad 380$. https://doi.org/10.15294/biosaintifika.v9i3.9424.

Islam, A., Nath, A. D., Islam, K., Islam, S., Chakma, S., \& Hossain, M. B. (2016). Isolation, identification and antimicrobial resistance profile of Staphylococcus aureus in Cockroaches (Periplaneta americana). 7710(September), 1-8.

Kassiri, H., Kasiri, A., \& Quaderi, A. (2014). Detection and Prevalence Rate of American Cockroaches (Periplaneta americana) Bacterial Infections in Human Dwellings. 9(4), 3-5. https://doi.org/10.5812/archcid.18737.

Khakim, L., \& Rini, C. S. (2018). Identifikasi Eschericia coli dan Salmonella sp. pada air kolam renang candi Pari. Journal of Medical Laboratory Science Atau Tecnology, 1(2), 84-93. https://ejournal3.undip.ac.id/

Kirby, W., Bauer, A., Sherris, J., \& Turk, M. (1966). Antibiotic susceptibility testing by standard single disk method. American Journal of Clinical Pathology, 45, 493-496.

Kundera, I. N., \& Bialangi, M., (2018). Sensitivitas Bakteri Gram Negatif yang Diisolasi dari Kaki Kecoa (Periplaneta americana) di Area Rumah Sakit dan Perumahan di Kota Palu terhadap Beberapa Antibiotik The Sensitivity of Gram Negative Bacteria Isolated from Cockroach Foot (Periplaneta americana). 15, 709714.

Lai, K. M. (2017). Are cockroaches an important source of indoor endotoxins? International Journal of Environmental Research and Public Health, 14(1). https:/ /doi.org/10.3390/ijerph14010091.

Leão-Vasconcelos, L. S. N. De O., Lima, A. B. M., Costa, D. De M., Rocha-Vilefort, L. O., Oliveira, A. C. A. De, Gonçalves, N. F., Vieira, J. D. G., \& Prado-Palos, M. A. (2015). Enterobacteriaceae Isolates From the Oral Cavity of Workers in a Brazilian Oncology Hospital. Revista Do Instituto de Medicina Tropical de São Paulo, 57(2), 121-127. https:/ / doi.org/10.1590/s0036-46652015000200004.

Leshan Wannigama, D., Dwivedi, R., \& Zahraei-Ramazani, A. (2013). Prevalence and antibiotic resistance of gram-negative pathogenic bacteria species isolated from Periplaneta americana and Blattella germanica in Varanasi, India. Journal of Arthropod-Borne Diseases, 8(1), 10-20.

Moges, F., Eshetie, S., Endris, M., Huruy, K., Muluye, D., Feleke, T., Silassie, F. G., Ayalew, G., \& Nagappan, R. (2016). Cockroaches as a Source of High Bacterial Pathogens with Multidrug Resistant Strains in Gondar Town, Ethiopia. 2016. https://doi.org/10.1155/2016/2825056.

Nedelchev, S., Pilarska, D., Takov, D., \& Golemansky, V. (2013). Protozoan and nematode parasites of the American coakroach Periplaneta americana (L.) from Bulgaria. Acta Zoologica Bulgarica, 65(3), 403-408.

Nurcahyo et.al.,(2012). Molecular Detection of Toxoplasmosis Using Specific Primers P30 , B1, and rDNA. 13(1), 9-13.

Pechal, J. L., Crippen, T. L., Tarone, A. M., Lewis, A. J., Tomberlin, J. K., \& Benbow, M. E. (2013). Microbial community functional change during vertebrate carrion decomposition. PLoS ONE, 8(11). https://doi.org/10.1371/journal.pone.0079035.

Syed, R., Manzoor, F., Adalat, R., Abdul-sattar, A., \& Syed, A. (2014). Laboratory Evaluation of Toxicity of Insecticide Formulations from Different Classes against American Cockroach (Dictyoptera: Blattidae). 8(June), 21-34.

Tatang, R. J. A., Tsila, H. G., \& Poné, J. W. (2017). Medically Important Parasites Carried by Cockroaches in Melong Subdivision, Littoral, Cameroon. 2017.

Zacharia, V. M., Manzanillo, P. S., Nair, V. R., Marciano, D. K., Kinch, L. N., Grishin, N. V., Cox, J. S., \& Shiloh, M.U. (2013). Cor, a novel carbon monoxide resistance gene, is essential for Mycobacterium tuberculosis pathogenesis. MBio, 4(6), 1-9. https://doi.org/10.1128/mBio.00721-13 
Kundera, I.N., Sapu, E. H., Bialangi, M. 2020. Antibiotics, isolation, Periplaneta americana, sensivity

\section{Supplementary}

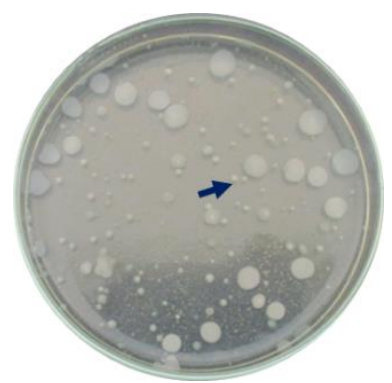

Figure 1. Colonies of bacteria on medium Nutrient Agar

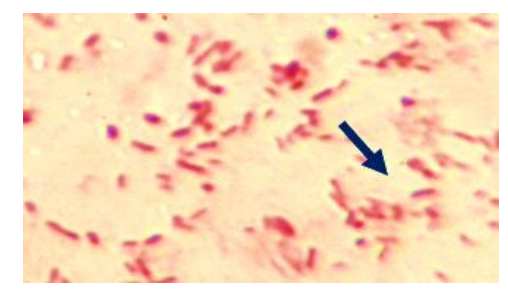

Figure 3. Escherichia coli cells Gram staining results, the cell looks like a red stem

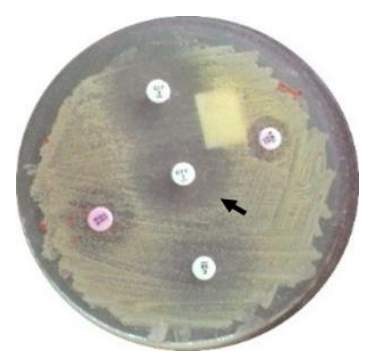

Figure 5. Antibiotic inhibition zone against Klebsiella pneumoniae

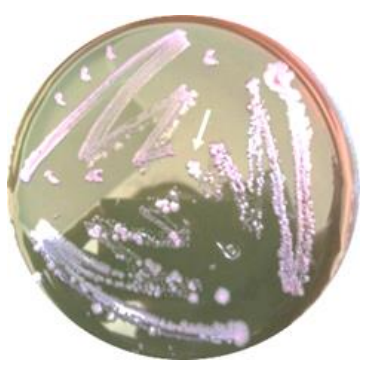

Figure 2. Colonies of E. coli bacteria on EMB-Agar medium

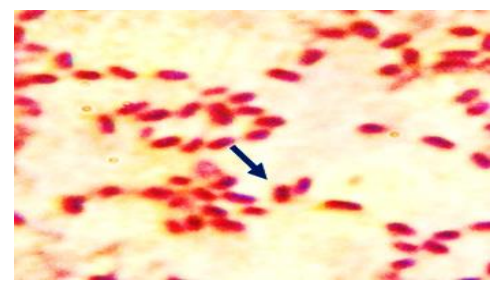

Figure 4. Salmonella arizona bacteria cells, the cell looks like a red stem

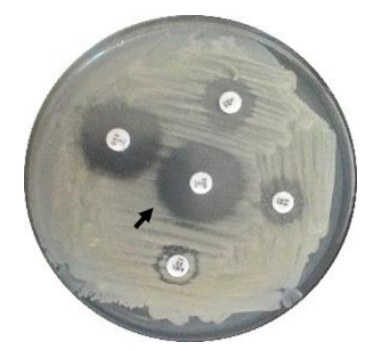

Figure 6. Antibiotic inhibition zone against Salmonella arizonae 
TECHNO: Vol. 09 (01) Mei 2020

Table 1. Microbact system biochemical test results

\begin{tabular}{clc}
\hline Sample & \multicolumn{1}{c}{ Type of Bacteria } & Validity Level (\%) \\
\hline A & Klebsiella pneumoniae & 79,33 \\
B & Proteus vulgaris & 95,59 \\
C & Escherichia coli & 82,86 \\
D & Klebsiella pneumoniae & 97,74 \\
E & Proteus vulgaris & 99,52 \\
F & Escherichia coli & 82,84 \\
G & Proteus mirabilis & 99,95 \\
H & Salmonella arizonae & 87,74 \\
\hline
\end{tabular}

Validity Level results are the results of a microbat system software analysis to determine the type of bacteria that was isolated from Cockroach feet. A to $\mathbf{H}$ bacterial sample code.

Table 2. The diameter of an inhibitory zone of antibiotic sensitivity test to bacteria

\begin{tabular}{|clccccc|}
\hline \multirow{2}{*}{ No } & \multirow{2}{*}{ Type of bacteria } & \multicolumn{5}{c|}{ The diameter zone of antibiotic } \\
inhibition \\
\cline { 3 - 7 } & & $\mathbf{A}$ & $\mathbf{B}$ & $\mathbf{C}$ & $\mathbf{D}$ & $\mathbf{E}$ \\
\hline $\mathbf{1}$ & Escherichia coli & $\mathbf{1 2}(\mathbf{i})$ & $\mathbf{5}(\mathbf{r})$ & $\mathbf{0}(\mathbf{r})$ & $23(\mathrm{~s})$ & $18(\mathrm{~s})$ \\
\hline $\mathbf{2}$ & Salmonella arizonae & $\mathbf{1 1}(\mathbf{i})$ & $\mathbf{5}(\mathbf{r})$ & $\mathbf{6}(\mathbf{r})$ & $20(\mathrm{~s})$ & $\mathbf{1 1}(\mathbf{i})$ \\
\hline $\mathbf{3}$ & Proteus vulgaris & $\mathbf{1 0}(\mathbf{r})$ & $\mathbf{5}(\mathbf{r})$ & $\mathbf{0}(\mathbf{r})$ & $23(\mathrm{~s})$ & $20(\mathrm{~s})$ \\
\hline $\mathbf{4}$ & Klebsiella pneunomiae & $\mathbf{9 ( r )}$ & $\mathbf{1 1}(\mathbf{i})$ & $\mathbf{0}(\mathbf{r})$ & $22(\mathrm{~s})$ & $23(\mathrm{~s})$ \\
\hline $\mathbf{5}$ & Proteus mirabilis & $20(\mathrm{~s})$ & $\mathbf{1 2 ( I )}$ & $\mathbf{7}(\mathbf{r})$ & $25(\mathrm{~s})$ & $\mathbf{1 1 ( i )}$ \\
\hline
\end{tabular}

The results of the measurement of bacterial sensitivity resulting from the isolation of Cockroach feet against some antibiotics, which is evidenced by the presence of bacteria that are Multi-Drug Resistant to some bacteria against antibiotics, which are commonly used in basic health services. $\mathbf{A}=$ Chloramphenicol $(30 \mu \mathrm{g}), \mathbf{B}=$ Amoxicillin $(20 \mu \mathrm{g}), \mathbf{C}=$ Vancomycin $(30 \mu \mathrm{g}), \mathrm{D}=$ Ciprofloxacin $(5 \mu \mathrm{g})$, dan $\mathbf{E}=$ Ofloxacin $(5 \mu \mathrm{g}), \quad \mathrm{r}=$ resisten, $\mathrm{i}=$ intermediet, dan $\mathrm{s}=$ sensitive. 